\title{
Macronutrient status of tall and short forms of Spartina alterniflora in a South Carolina salt marsh
}

\author{
W. Harold Ornes ${ }^{1}$, Daniel I. Kaplan ${ }^{2}$ \\ ${ }^{1}$ Department of Biology, University of South Carolina, Aiken, South Carolina 29801, USA \\ and \\ Belle W. Baruch Institute for Marine Biology and Coastal Research, University of South Carolina, Columbia, South Carolina \\ 29208, USA \\ ${ }^{2}$ Biogeochemistry Division, Savannah River Ecology Laboratory, Drawer E, Aiken, South Carolina 29801, USA
}

\begin{abstract}
Macronutrient concentration in shoot (all aboveground live biomass) and root (all belowground live biomass) tissues of tall (TS) and short Spartina alterniflora (SS) were measured monthly in North Inlet Estuary, Winyah Bay, South Carolina, USA. Seasonal changes in shoot N, P, and S concentrations occurred both in TS and SS, while root macronutrient concentrations remained constant throughout the seasons (seasonal root data not presented). Macronutrient concentrations between the 2 forms of $S$ alterniflora also differed. Concentrations of $\mathrm{N}$ (as $\mathrm{NH}_{4}^{+}$) were greater in the shoots and roots of TS than in SS. Sulfur, however, was greater in SS shoots and roots than in TS. Interstitial waters at the SS site had lower $\mathrm{Fe}$ and redox potentials than the TS site. These conditions would result in higher sulfide levels which also decrease plant production. We suggest that decreased growth occurred when $\mathrm{S}$ was above the critical concentrations of $0.5 \%$ in shoots and $1.0 \%$ in roots. Our data support the hypothesis that differences in the nutritional status between TS and SS may account for the height and biomass differences between the 2 populations.
\end{abstract}

\section{INTRODUCTION}

Researchers recognize 2 or 3 growth forms of Spartina alterniflora Loisel. The tall form (about $1.5 \mathrm{~m}$ ) is found along estuarine creeks and the short form labout $0.5 \mathrm{~m}$ ) in high marsh, upland areas. An intermediate form may be found between these 2 sites. Evidence indicates that these height forms are ecophenes and that environmental differences are responsible for the Spartina marsh zonation (Shea et al. 1975, Anderson \& Treshow 1980). Short-term research results indicate environmental factors that can influence $S$. alterniflora height and production include salinity (Miller \& Egler 1950, Adams 1963, Phleger 1971, Chalmers 1979, Giurgevich \& Dunn 1979, Anderson \& Treshow 1980 , Linthurst \& Seneca 1981, Gosselink 1984); nitrogen (Broome et al. 1975, Eley et al. 1975, Chalmers 1979. Giurgevich \& Dunn 1979, Anderson \& Treshow 1980, Gallagher et al. 1980, DeLaune et al. 1981, Linthurst \& Seneca 1981, Gosselink 1984, Hopkinson \& Schubauer 1984, Smith 1984, Valiela 1984, Wolaver \& Zieman
1984); and sulfur and/or redox potential (Howarth \& Teal 1979, Linthurst 1979, Howes et al. 1981, Carlson \& Forest 1982, King et al. 1982, DeLaune et al. 1983, Giblin \& Howarth 1984). These and other short-term field studies show that factors which affect $S$. alterniflora growth are many and complex, making a comprehensive predictive model for Spartina saltmarsh production difficult and as yet undeveloped.

We tested the hypothesis that differences in the nutritional status of tall Spartina alterniflora (TS) and short $S$. alterniflora (SS) could account for the growth differences between the 2 populations. Biomass, height, and density of both forms were quantified by Dame \& Kenny (1986) for the study site at North Inlet Estuary, Winyah Bay, South Carolina, USA. We took samples from that study for analysis of nutrient contents. Although previously cited studies have reported on selected macronutrients, this study reports the complete macronutrient status of the shoots for $46 \mathrm{mo}$ and roots for $15 \mathrm{mo}$ in both forms in a relatively pristine saltmarsh. 


\section{METHODS}

The North Inlet saltmarsh and estuary covers ca $32 \mathrm{~km}^{2}$ near Georgetown, South Carolina, USA. Spartina alterniflora exists in this area in near-monoculture stands and can be found as the tall form on the creek banks and as the short form near the uplands. On average, the marsh is covered by water $30 \%$ of the time (Kjerfve et al. 1982) and has a yearly-average salinity of $34.6 \mathrm{ppt}$. A more detailed description of our research area is given by Dame \& Kenny (1986).

Tall Spartina alterniflora plants were collected from a site along the edges of Bread and Butter Creek $(3 \mathrm{~m}$ from the creek edge). Short $S$. alterniflora plants were collected from a site ca $1 \mathrm{~km}$ inland from the TS site at the upper reaches of Bly Creek. Both sites were sufficiently large to ensure that less than $10 \%$ of the total area would be cut during 5 yr of monthly sampling.

Biomass and macronutrient concentrations in shoots (leaf and stem) were determined monthly from June 1981 through March 1985. Shoot biomass, density and plant height measurements were determined from $0.25 \mathrm{~m}^{2}$ plots. The TS measurements were replicated monthly using 10 plots and the SS measurements were replicated using 5 plots, which provided mean estimates with coefficients of variability of less than $20 \%$. Generally 3 of the replicate plots were randomly selected each month for nutrient analyses. Live and dead material was separated and chemical analyses of live material only are reported here.

Root tissue samples were collected monthly from July 1983 to September 1984. Biomass and density measurements were determined from $0.25 \mathrm{~m}^{2}$ plots. Statistical analysis indicated that 8 cores from the TS site and 12 cores from the SS site were necessary to obtain variability of $20 \%$ or less. Cores containing root and rhizome material were taken from the plots harvested for root biomass. Each core was $10.2 \mathrm{~cm}$ in diameter and $40 \mathrm{~cm}$ deep. Core samples were washed to remove soil. Live and dead root tissues were separated. Generally 3 of the replicated plots were randomly selected each month for nutrient analyses.

Subsamples were ground to pass a 40 -mesh $(354 \mu \mathrm{m})$ screen and analyzed for the macronutrients nitrogen $(\mathrm{N})$ phosphorus $(\mathrm{P})$, potassium $(\mathrm{K})$, calcium $(\mathrm{Ca})$, magnesium $(\mathrm{Mg})$, and sulfur (S). N was determined by the Kjeldahl method and $\mathrm{P}$ by the ascorbic acid method (Council on Soil Testing and Plant Analysis 1980). The elements K $\mathrm{Ca}$, and $\mathrm{Mg}$ were determined by atomic absorption spectrophotometry (Council on Soil Testing and Plant Analysis 1980). Sulfur was determined by the turbidimetric (Butters \& Chenery 1959) or the Leco combustion methods (Council on Soil Testing and Plant Analysis 1980). The turbidimetric and Leco methods of determining $S$ have been found to be comparable (Jones \& Isaac 1972),
Soil samples were collected 4 times in both the tall and short Spartina alterniflora sites (November 1981, February 1982, May 1982, and August 1982). Samples were collected at $2.5 \mathrm{~cm}$ interval depths from the surface to a depth of $27.5 \mathrm{~cm}$. Means of selected chemical parameters were calculated by combining depths 0 to $7.5,10$ to 17.5 , and 20 to $27.5 \mathrm{~cm}$ (Table 4). Redox potential (Eh) measurements were made with $5 \mathrm{~mm}$ platinum electrodes and a Corning model 130 meter (Corning Instrument Company, Corning, New York, USA). The electrodes were inserted into sealed chambers taken from appropriate depths and allowed to equilibrate for $3 \mathrm{~h}$ before a reading was recorded Sulfide was determined using the method described by DeLaune et al. (1983). Samples were centrifuged to remove interstitial water and the supernatant was filtered through a $0.45 \mu \mathrm{m}$ filter, acidified, and stored frozen until analyzed. Samples were analyzed for $K$, $\mathrm{Ca}, \mathrm{Mg}$, and Fe by atomic absorption spectrophotometry (AAS). Orthophosphate (Murphy \& Riley 1962) and ammonia (O'Brien \& Fiore 1962) were analyzed with the use of an Autoanalyzer II system (Technicon Instrument Company, Terrytown, New York, USA), while total dissolved phosphorus (TDP), and total dissolved nitrogen (TDN) were determined by a modified Kjeldhal digest procedure and a Technicon block digestor (Kammerer et al. 1967).

Data were analyzed by the general linear model procedure in the SAS computer program (SAS 1985). Mean separation was conducted using Duncan's New Multiple Range Test and Pearson's correlation coefficients were used to estimate goodness of fit within simple regression analysis.

\section{RESULTS AND DISCUSSION}

Spartina alterniflora tissues were selected randomly from the samples collected by Dame \& Kenny (1986) in North Inlet and analyzed chemically for the mineral nutrient contents. The monthly aboveground biomass and height were significantly greater in TS than in SS throughout each year (Table 1; Fig. 1). Plant density, however, was greater in SS than in TS throughout each year. Belowground biomass at North Inlet estuary was higher in SS than in TS. Over a 15 mo period, $96.2 \%$ of the biomass of SS was roots and rhizomes, compared to $83.9 \%$ for TS.

\section{Nitrogen}

Shoot $N$ concentrations of both TS and SS followed similar seasonal patterns (Fig. 2). Live shoot tissue $N$ concentrations began to increase in December (2 mo after shoot lengths and biomass had peaked) and 
Table 1. Spartina alterniflora. Yearly means of tall (TS) or short (SS) form shoot or root macronutrient concentrations, biomass, density, and plant heights. Values in a row followed by the same letter are not significantly different $(p<0.05$, Duncan's Multiple Range Test). Shoot data represent means from 46 mo of data; $n \geqq 120$. Root data represent means from 15 mo of data; $n \geqq 34$ Growth parameter data from Dame \& Kenny (pers. comm.)

\begin{tabular}{|lcccc|}
\hline Nutrient & \multicolumn{2}{c}{ Shoot } & & Root \\
& TS & SS & TS & SS \\
\hline $\mathrm{N}(\%)$ & $1.32 \mathrm{a}$ & $1.20 \mathrm{~b}$ & $0.62 \mathrm{a}$ & $0.56 \mathrm{~b}$ \\
$\mathrm{P}(\%)$ & $0.19 \mathrm{a}$ & $0.16 \mathrm{a}$ & $0.14 \mathrm{a}$ & $0.08 \mathrm{a}$ \\
$\mathrm{K}(\%)$ & $1.23 \mathrm{a}$ & $1.29 \mathrm{a}$ & 0.622 & $0.36 \mathrm{~b}$ \\
$\mathrm{Ca}(\%)$ & $0.26 \mathrm{a}$ & $0.22 \mathrm{a}$ & $0.11 \mathrm{a}$ & $0.12 \mathrm{a}$ \\
$\mathrm{Mg}(\%)$ & $0.35 \mathrm{a}$ & $0.35 \mathrm{a}$ & $0.32 \mathrm{a}$ & $0.30 \mathrm{a}$ \\
$\mathrm{S}(\%)$ & $0.32 \mathrm{~b}$ & $0.81 \mathrm{a}$ & $0.89 \mathrm{~b}$ & $1.21 \mathrm{a}$ \\
Biomass $\left(\mathrm{g} \mathrm{m}^{-2}\right)$ & $439.1 \mathrm{a}$ & $150.1 \mathrm{~b}$ & $2282.8 \mathrm{~b}$ & $3791.6 \mathrm{a}$ \\
Density (plants m$\left.{ }^{-2}\right)$ & $113 \mathrm{~b}$ & $741 \mathrm{a}$ & - & - \\
Plant height $(\mathrm{cm})$ & $105.0 \mathrm{a}$ & $29.3 \mathrm{~b}$ & - & - \\
\hline
\end{tabular}

reached a maximum in February of $1.87 \%$ in TS and $1.59 \%$ in SS. From February, shoot $\mathrm{N}$ concentrations decreased to the lowest values of the year (about $0.98 \% \mathrm{~N}$ in $\mathrm{TS} ; 1.00 \% \mathrm{~N}$ in SS) during the period July through November. This apparent decrease in $\mathrm{N}$ occurred primarily because of a dilution of tissue $\mathrm{N}$ as the aerial biomass of the TS and SS increased during this same period (Fig. 1). During the active spring growing period, stem $\mathrm{N}$ was utilized and diluted by increasing plant biomass, which resulted in the lower fall tissue concentrations of $N$ (Fig. 2). The dilution effect was further evidenced by the negative correlation coefficients observed between $N$ concentration and plant length or biomass (Table 2). In their model predicting yield of Spartina alterniflora, Woodhouse et al. (1974) obtained a positive correlation between yield and tissue $\mathrm{N}$ content in June, while at the end of September the correlation was negative. They reasoned that high concentrations of $\mathrm{N}$ in winter were indicative of high growth potential while at maturity (September) N concentrations were lowest in plants that had achieved the greatest growth and hence the greatest amount of $\mathrm{N}$ dilution.

Stem $\mathrm{N}$ concentrations in both Spartina alterniflora forms from North Inlet were in the range of values reported by other investigators (Table 3 ) and were above the critical concentrations of $0.7 \%$ (below which would limit growth) experimentally derived by Smart \& Barko (1980). Based on Smart \& Barko's results, $N$ in North Inlet did not appear to be limiting.

Researchers have reported increased SS growth with $\mathrm{N}$ fertilization. Gallagher (1975) observed a rapid growth response when $N$ (as ammonium nitrate) was applied to SS plots, but no response in TS plots. The author inferred from this that SS plants were $\mathrm{N}$ deficient. Others also have demonstrated increased growth following $\mathrm{N}$ fertilization (Sullivan \& Daiber 1974, Valiela \& Teal 1974, Broome et al. 1975, Valiela et al. 1975.
1976, Mendelssohn 1979b). However, Morris (1980) showed that $\mathrm{N}$ uptake in SS should not be limited by $\mathrm{NO}_{3}$ availability since the affinity constant for $\mathrm{NO}_{3}\left(\mathrm{~K}_{5}\right)$ is lower than ambient $\mathrm{NO}_{3}$ concentrations. The enhanced plant growth noted after $N$ fertilization by the above researchers may be a secondary response after an unknown limiting factor was amended. Nitrogen fertilization may have overcome the effect of sulfide toxicity or high salinity, which may have been limiting growth. For example, Shea et al. (1975) were able to alleviate both temperature and salinity stress in Spartina alterniflora by applying additional N. Stevenson (1982) reported that $\mathrm{N}$ additions to an anaerobic marsh soil may generate a variety of responses including changes in microbial activity, microbial populations, redox potential, acidity, and specific ion concentrations.

Monthly root $\mathrm{N}$ concentrations did not fluctuate significantly throughout the year (root concentrations not presented). However, the 15 mo average root $\mathrm{N}$ concentration of TS was significantly greater $(p<0.05, n=$ 41) than SS (Table 1).

\section{Phosphorus}

The pattern of monthly fluctuations of shoot $\mathrm{P}$ concentrations closely paralleled those of shoot $\mathrm{N}$ concentrations (Fig. 2). The Pearson's correlation coefficients between shoot $\mathrm{P}$ and $\mathrm{N}$ for $\mathrm{TS}$ and SS were 0.93 and 0.76 (both $p<0.001, n=128$ ), respectively. Gallagher et al. (1980) reported P concentrations were greater in SS than TS during the growing season. In winter, however, they found that $\mathrm{P}$ concentrations of TS were equal to or above those in SS. In North Inlet we found no statistically significant $(p>$ 0.05 ) differences between TS and SS in either shoot or root $\mathrm{P}$ concentrations over the study periods 


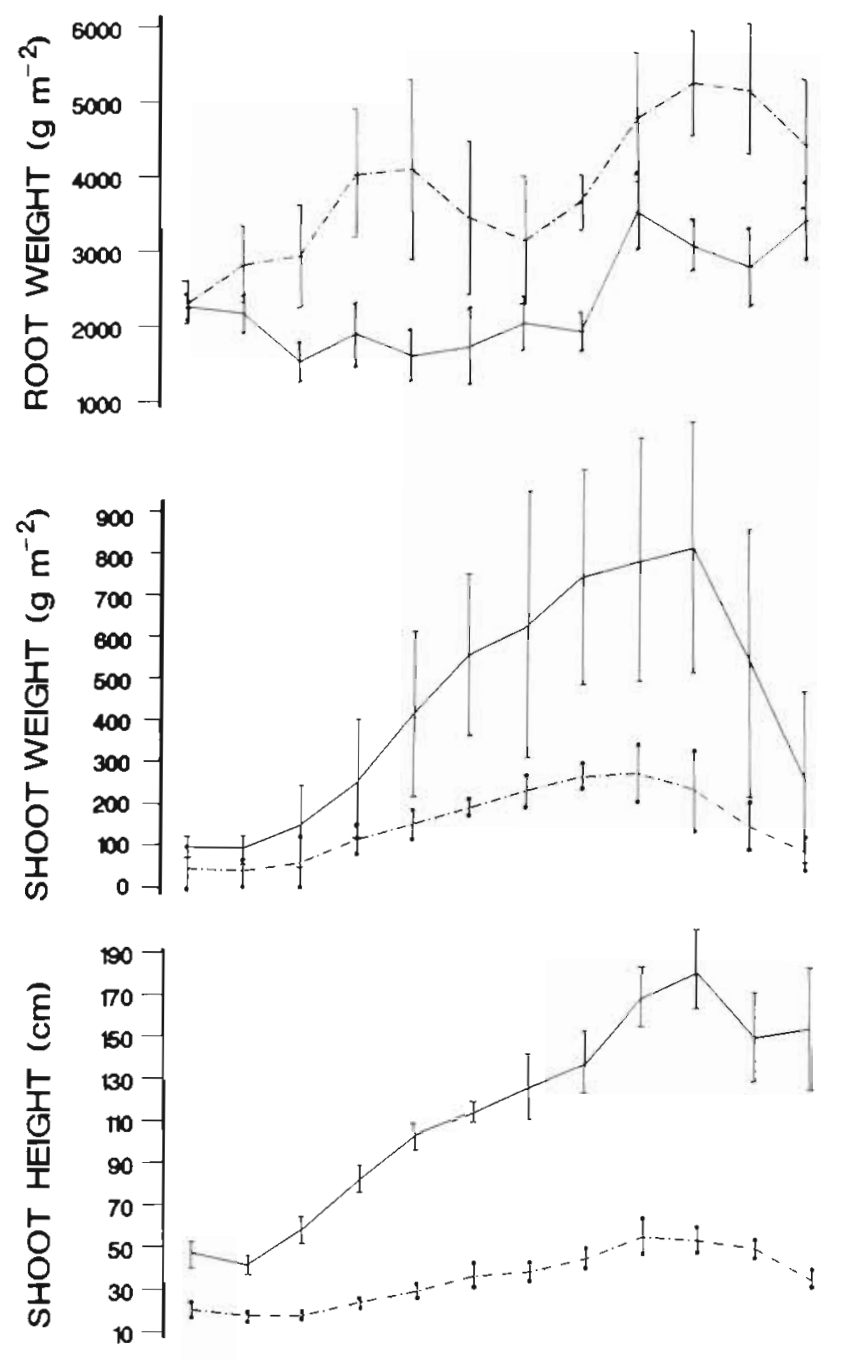

(Table 1). Therefore, $\mathrm{P}$ was probably not a limiting factor in our study. Whitney et al. (1981) reported that $P$ is seldom limiting in salt marshes and Patrick \& DeLaune (1976) found that $P$ additions did not affect plant growth. Furthermore, through a greenhouse study conducted by Smart \& Barko (1980), the critical concentration of $\mathrm{P}$ was calculated to be $0.44 \mathrm{mg}$ $\mathrm{P} \mathrm{kg}^{-1}$. All the shoot and root $\mathrm{P}$ concentrations from North Inlet were well above this critical concentration and within the range reported by other investigators (Table 3).

\section{Potassium, calcium and magnesium}

There were no significant differences between TS and SS shoot concentrations of $\mathrm{K}, \mathrm{Ca}$ and $\mathrm{Mg}$ (Table 1). The similarity of their seasonal dynamics in shoots of TS and SS is shown in Fig. 2. Unlike the dramatic seasonal changes observed for $\mathrm{N}$ and $\mathrm{P}$, the concentrations of $\mathrm{K}, \mathrm{Ca}$, and $\mathrm{Mg}$ did not change significantly over time. Shoot length and biomass of SS were positively correlated to $\mathrm{Ca}$ and $\mathrm{Mg}$ concentrations (Table 2). This suggests that Ca and Mg may be limiting to SS, however such correlations do not prove a cause and effect relationship.

Root concentrations of $\mathrm{Ca}$ and $\mathrm{Mg}$ were generally similar in the TS and SS except that $K$ was significantly greater in TS than in SS $(p<0.05, n=41)$ (Table 1 ).

\section{Sulfur}

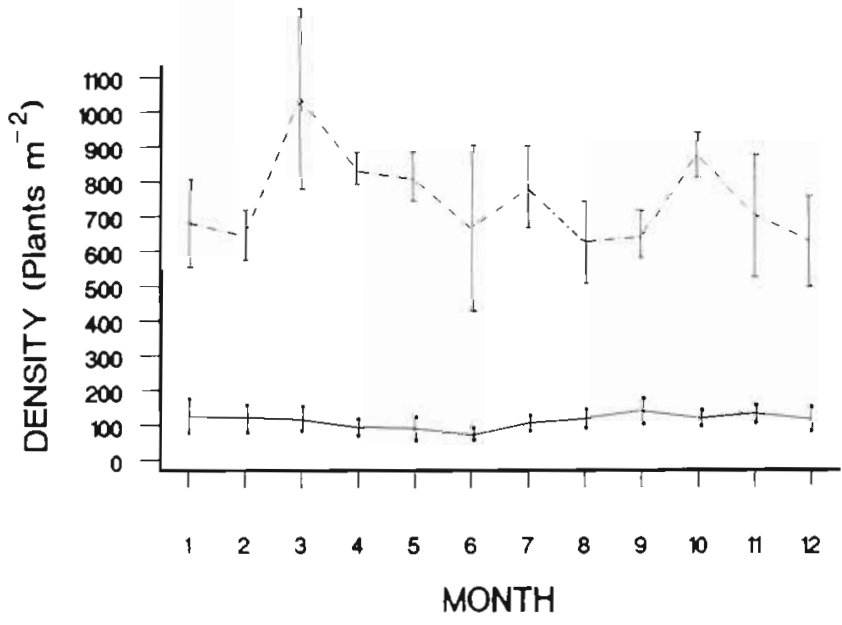

Fig. 1. Spartina alterniflora. Monthly means and standard deviations of root weight, shoot weight, shoot height, and plant density for tail (solid line) and short (broken line) forms. Data supplied by R. Dame (pers. comm.). Root weight means with standard deviations calculated from 8 samples TS and 1.2 samples SS each month

Monthly and yearly means of shoot $\mathrm{S}$ concentrations were significantly $(p<0.05)$ greater in SS than in TS (Table 1; Fig. 2). Short Spartina alterniflora shoot S concentrations averaged $0.81 \%$ and TS averaged $0.32 \%$ $(p<0.001, n=152)$ (Table 1$)$. Root $\mathrm{S}$ concentrations averaged $1.21 \%$ in SS and $0.89 \%$ in TS $(p<0.001, n=$ 36) (Table 1). The ratio of root $S$ concentration to shoot $\mathrm{S}$ concentration in SS was 1.5:1. The significantly lower ratio $(2.8: 1)$ found in TS indicates that a greater proportion of $\mathrm{S}$ was being transported to the shoots in SS than was being transported to shoots in TS (Table 1; Fig. 2). Other researchers have found that $S$ concentrations in aerial portions of $S$. alterniflora were negatively correlated with growth (Broome et al. 1975, Linthurst 1979).

Further examination of the data suggested that there were critical concentrations of $\mathrm{S}$ above which only SS occurred (Fig. 3). For shoot biomass, shoot height, and plant density, the critical shoot $\mathrm{S}$ concentration was estimated to be about $0.50 \%$ (Fig. 3). For root weight, the critical root $\mathrm{S}$ concentration was $1.0 \% \mathrm{~S}$. 


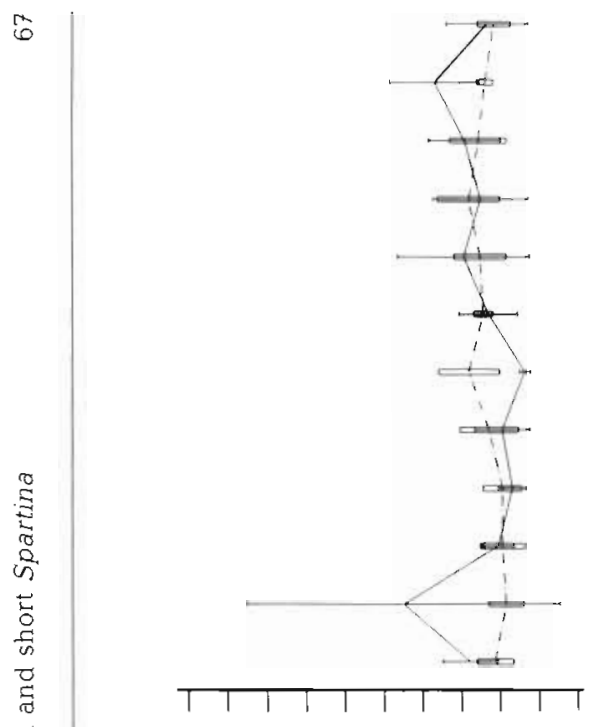

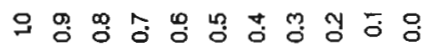
(\%) พกเวาษว

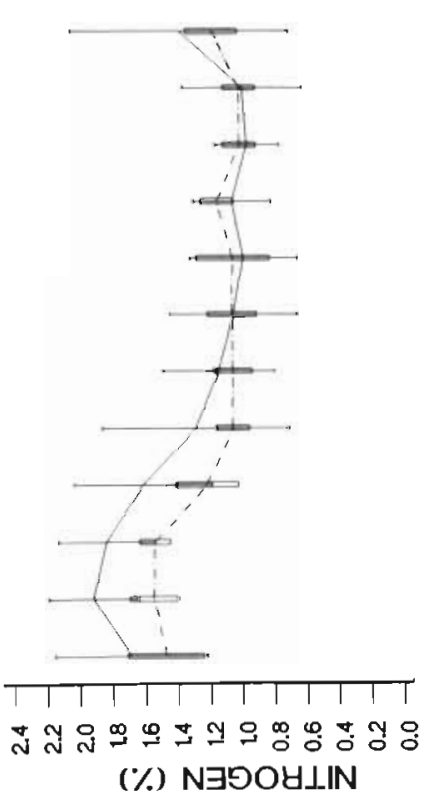

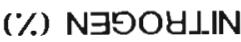
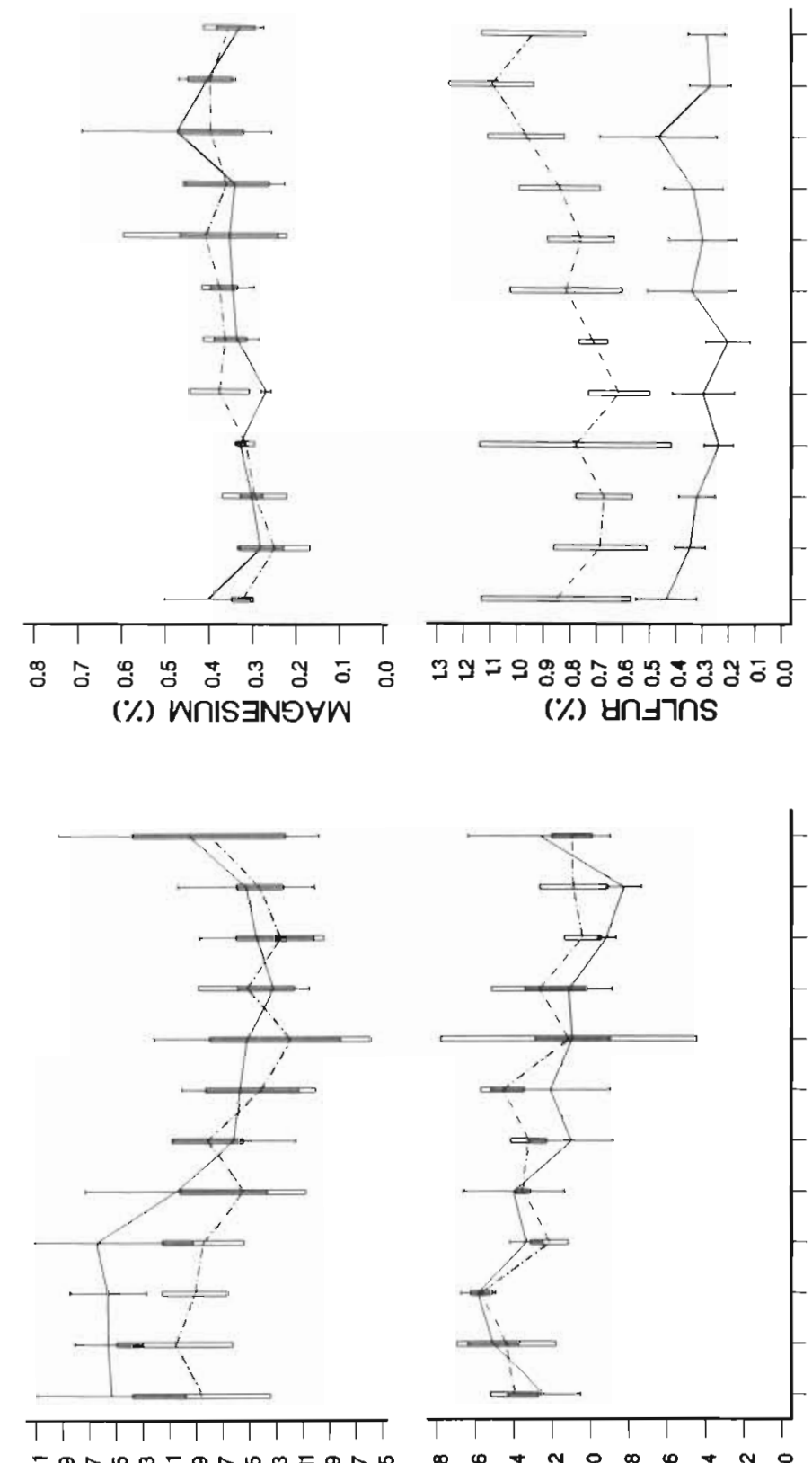

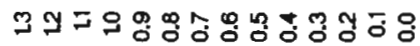

(\%) 4 แกษากร
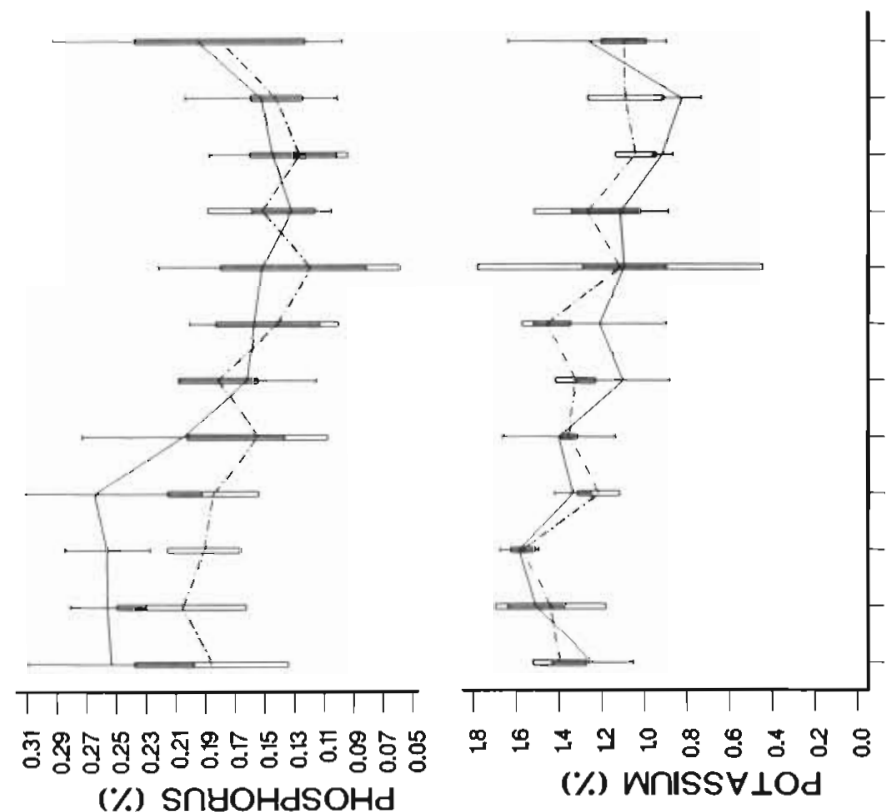

(\%) WnISS $\forall \perp O d$

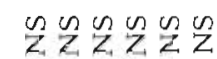

芩

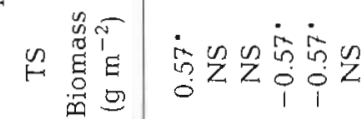

人 至

is

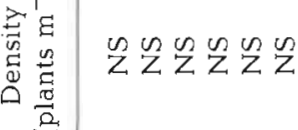

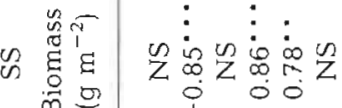

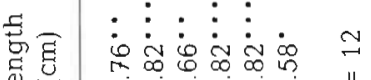
00000

$=$

$\Omega$

$\infty$

工

- 을

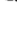

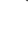

$\sim$ 
Table 3. Spartina alterniflora. Reported macronutrient concentrations (\%) for shoot tissues. TS: tall form; SS: short form

\begin{tabular}{|c|c|c|c|c|c|c|c|c|c|c|c|c|}
\hline \multirow[t]{2}{*}{ Source } & \multicolumn{2}{|c|}{$\mathrm{N}$} & \multicolumn{2}{|c|}{$\mathrm{P}$} & \multicolumn{2}{|c|}{$K$} & \multicolumn{2}{|c|}{$\mathrm{Ca}$} & \multicolumn{2}{|c|}{$\mathrm{Mg}$} & \multicolumn{2}{|c|}{$\mathrm{S}$} \\
\hline & TS & SS & TS & SS & TS & SS & TS & SS & TS & SS & TS & SS \\
\hline This study & 1.32 & 1.20 & 0.19 & 0.16 & 1.23 & 1.29 & 0.26 & 0.22 & 0.35 & 0.35 & 0.32 & 0.81 \\
\hline Linthurst \& Seneca (1981) & 1.07 & 1.20 & 0.20 & 0.18 & 1.28 & 1.16 & 0.30 & 0.26 & 0.35 & 0.40 & 0.35 & 0.46 \\
\hline Broome et al. (1986) & \multicolumn{2}{|c|}{0.7} & \multicolumn{2}{|c|}{0.09} & \multicolumn{2}{|c|}{0.78} & \multicolumn{2}{|c|}{0.25} & \multicolumn{2}{|c|}{0.46} & \multicolumn{2}{|c|}{0.50} \\
\hline Gallagher et al. (1980) & 1.0 & 0.80 & 0.17 & 0.17 & 1.0 & 1.0 & 0.15 & 0.15 & 0.33 & 0.33 & - & - \\
\hline Carlson \& Forrest (1982) & - & - & - & - & - & - & - & - & - & - & & \\
\hline Mendelssohn $(1979 b)$ & 1.69 & 1.53 & - & - & - & - & - & - & - & - & - & - \\
\hline Linthurst $(1979)^{\circ}$ & \multicolumn{2}{|c|}{$0.78-0.88$} & \multicolumn{2}{|c|}{$0.11-0.12$} & \multicolumn{2}{|c|}{$1.02-1.43$} & \multicolumn{2}{|c|}{$0.15-0.30$} & \multicolumn{2}{|c|}{$0.24-0.30$} & \multicolumn{2}{|c|}{$0.21-0.49$} \\
\hline Broome et al. $(1975)^{a}$ & \multicolumn{2}{|c|}{$0.76-1.10$} & \multicolumn{2}{|c|}{0.09} & \multicolumn{2}{|c|}{$0.80-1.00$} & \multicolumn{2}{|c|}{$0.20-0.30$} & \multicolumn{2}{|c|}{$0.40-0.46$} & \multicolumn{2}{|c|}{$0.68-0.84$} \\
\hline Gallagher $(1975)^{\mathrm{a}}$ & \multicolumn{2}{|c|}{$0.7-0.9$} & \multicolumn{2}{|c|}{0.14} & - & - & - & - & - & - & - & - \\
\hline Patrick \& DeLaune $(1976)^{a}$ & \multicolumn{2}{|c|}{$0.7-0.9$} & \multicolumn{2}{|c|}{$0.08-0.15$} & - & - & - & - & - & - & - & - \\
\hline Chalmers (1979) & \multicolumn{2}{|c|}{1.40} & - & - & - & - & - & - & - & - & - & - \\
\hline Valiela $(1984)$ & \multicolumn{2}{|c|}{1.40} & - & - & - & - & - & - & - & - & - & - \\
\hline Hopkinson \& Schubauer (1984) & \multicolumn{2}{|c|}{1.05} & - & - & - & - & \multirow{2}{*}{\multicolumn{2}{|c|}{${ }^{-}{ }_{0.90^{-}}^{-}$}} & - & - & - & - \\
\hline Burkholder (1956) & - & - & & & _- & _- & & & _- & _. & _- & _- \\
\hline Smart \& Barko $(1980)^{b}$ & \multicolumn{2}{|c|}{$0.66-0.80$} & 0.04 & 0.05 & - & - & - & - & - & - & - & - \\
\hline
\end{tabular}
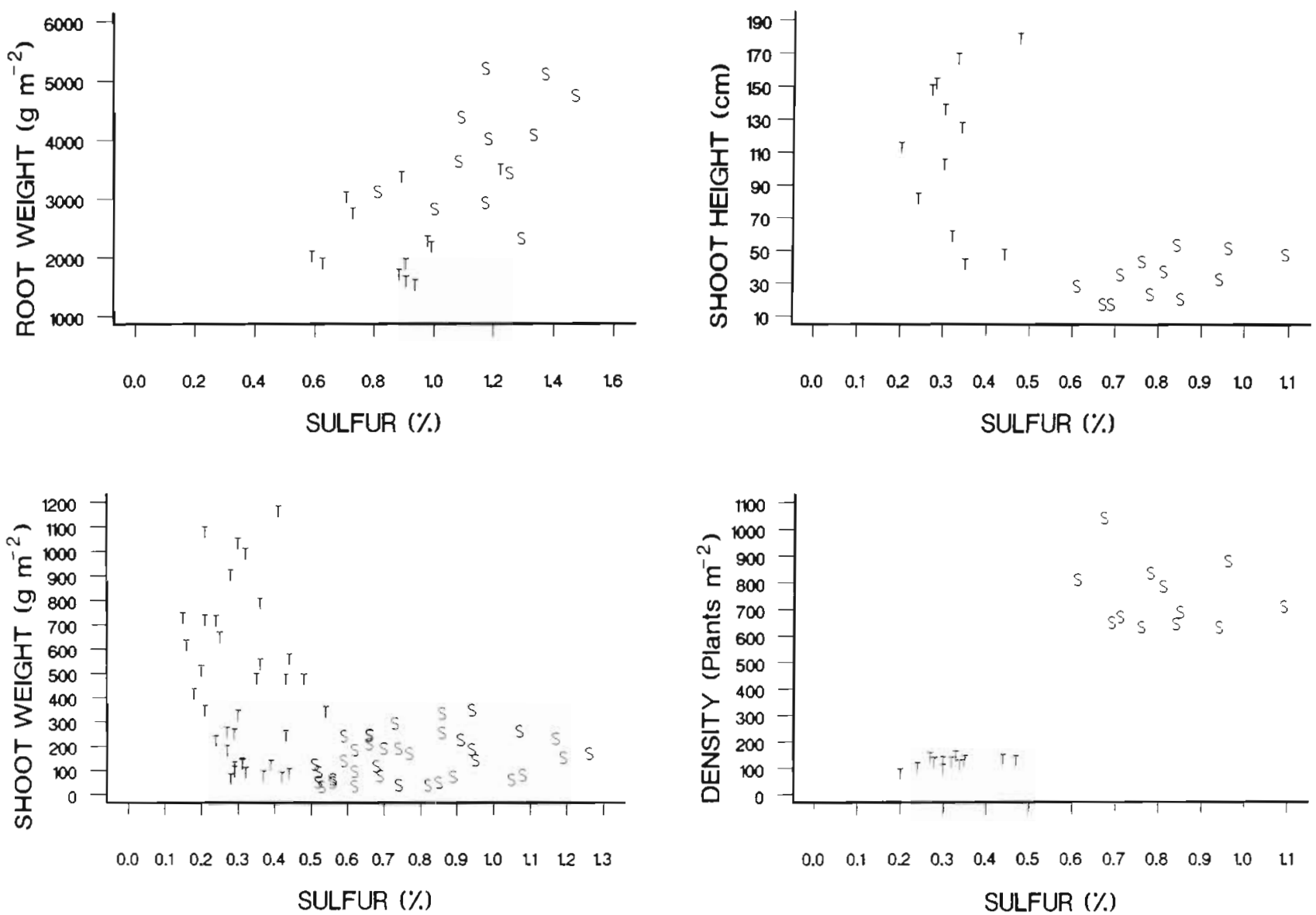

Fig. 3. Spartina altemiflora. Tissue S concentrations (\% dry wt) and root weight, shoot weight, shoot height, and plant density for tall (T) and short (S) forms 


\section{Substrate nutrient concentrations}

The literature suggests that high soil sulfide levels may (1) directly affect production by Spartina alterniflora as a result of increased mortality (Linthurst 1979, DeLaune et al. 1983), (2) inhibit the transport system involved in $\mathrm{N}$ uptake (Mendelssohn 1979a, Morris 1980, Howes et al. 1981, DeLaune et al. 1983), and (3) lower oxygen availability, thereby changing patterns of catabolism (Mendelssohn et al. 1981). Several researchers have suggested that depressed oxygen transport, which is conducive to denitrification, and sulfide toxicity may be the cause of stunted growth of S. alterniflora (Howes et al. 1981, Mendelssohn et al. 1981, King et al. 1982). Howarth \& Teal (1979) reported that sulfide concentrations as low as $0.20 \mathrm{mM}$ killed $S$. alterniflora plants grown hydroponically.

King et al. (1982) proposed that the gradients in the edaphic factors that regulate Spartina alterniflora production are controlled not only by interstitial sulfide concentration but also by the dynamic relationship among tidal water movement, iron concentration and bacterial sulfate reduction. Natural water movement in soil is much greater in TS than in SS marshes, as documented by several studies that reveal significant vertical and lateral movement in the TS areas and virtually no movement in the SS areas (Nestler 1977). In soils where water movement and aeration were increased, plant growth was stimulated; where movement was restricted, plant growth was inhibited (Linthurst 1979). In North Inlet, there was a significant $(p<0.05, n=16)$ difference in the average annual sediment redox potential (Eh) between the tall and short $S$. alterniflora sites at the 20 to $27.5 \mathrm{~cm}$ depth (Table 4). This result was not surprising since water flow was minimal at the SS site. In a similar comparison of TS and SS sites in Louisiana, USA, DeLaune et al.
(1983) found higher Eh levels only in the surface $10 \mathrm{~cm}$ site of the TS, while the lower depths at both sites had similar Eh values.

Sulfide concentrations varied markedly in Sapelo Island marshes (Georgia, USA) and were inversely correlated with soil water flow and plant production (Nestler 1977, Gallagher et al. 1980, Howes et al. 1981). DeLaune et al. (1983) reported that free sulfide concentrations greater than $10 \mathrm{mg} \mathrm{S} \mathrm{kg}{ }^{-1}$ dry soil adversely affected Spartina alterniflora and that root production was significantly reduced when the free sulfide concentration rose above $50 \mathrm{mg} \mathrm{S} \mathrm{kg}^{-1}$ dry soil. In North Inlet, the reduced substrate conditions co-existed with very high levels of free sulfide (average for all depths = $66 \pm 28.8 \mathrm{mg} \mathrm{SO}_{3} \mathrm{~kg}^{-1}$ dry soil; Table 4). King et al. (1982) reported a similar inverse relation between Eh and sulfide concentrations in interstitial water. S. alterniflora growing in these conditions had decreased plant heights and increased root biomass. The average sulfide level in TS soils (average for all depths $=13.3 \pm$ $1.2 \mathrm{mg} \mathrm{SO} \mathrm{Sg}^{-1}$ ) was significantly ( $p<0.05, n=16$ ) less than in the SS soils. In Louisiana, DeLaune et al. (1983) also noted a significant difference of free $\mathrm{S}^{-2}$, but not acid-soluble $\mathrm{S}^{-2}$, at the 20 to $27.5 \mathrm{~cm}$ depth between tall and short sites. They concluded that $\mathrm{S}$ was among the primary environmental factors responsible for the height difference in the 2 forms of $S$. alterniflora and that sulfide indirectly inhibited nitrogen uptake.

In our study, ammonia as well as total dissolved nitrogen concentrations were statistically $(p<0.05, n=$ 16) similar at both study sites, suggesting that $\mathrm{N}$ availability was not limiting SS growth. Although $\mathrm{N}$ is often proposed as limiting the growth of Spartina alterniflora based on increased productivity following fertilization, the addition of $\mathrm{N}$ to the plant may mask other nutrient problems such as sulfide toxicity (King et al. 1982). The

Table 4. Means of selected chemical properties of interstitial water extracted from 0 to $7.5,10$ to 17.5 , and 20 to $27.5 \mathrm{~cm}$ depth. Soil samples collected in November 1981, February 1982, May 1982, and August 1982. TS: tall form; SS: short form of Spartina alterniflora. TDN: total dissolved nitrogen; TDP: total dissolved phosphorus; Eh: redox potential. Means within a row and for the same soil depth are not significantly different if followed by the same letter $(p<0.05$, Duncan's Multiple Range Test, $n=16)$

\begin{tabular}{|c|c|c|c|c|c|c|c|}
\hline \multirow{2}{*}{\multicolumn{2}{|c|}{ Property }} & \multicolumn{2}{|c|}{$0-7.5 \mathrm{~cm}$} & \multicolumn{2}{|c|}{$10-17.5 \mathrm{~cm}$} & \multicolumn{2}{|c|}{$20-27.5 \mathrm{~cm}$} \\
\hline & & TS & SS & TS & SS & TS & SS \\
\hline $\mathrm{NH}_{4}-\mathrm{N}$ & $\left(\mathrm{mg} \mathrm{kg}^{-1}\right)$ & $95 a$ & $65 a$ & $113 a$ & $80 \mathrm{~b}$ & $86 a$ & $84 a$ \\
\hline $\mathrm{PO}_{4}$ & $\left(m g \mathrm{~kg}^{-1}\right)$ & $6 \mathrm{~b}$ & $11 a$ & $16 a$ & $10 \mathrm{~b}$ & $13 a$ & $13 a$ \\
\hline $\mathrm{SO}_{3}$ & $\left(\mathrm{mg} \mathrm{kg}{ }^{-1}\right)$ & $14 b$ & $34 a$ & $14 \mathrm{~b}$ & $90 \mathrm{a}$ & $12 b$ & $74 a$ \\
\hline $\mathrm{K}$ & $\left(\mathrm{mg} \mathrm{kg} \mathrm{kg}^{-1}\right)$ & $306 a$ & $296 a$ & $305 a$ & $285 b$ & $311 a$ & $299 a$ \\
\hline $\mathrm{Ca}$ & $\left(\mathrm{mg} \mathrm{kg} \mathrm{kg}^{-1}\right)$ & $334 a$ & $283 a$ & $316 a$ & $255 a$ & $311 \mathrm{a}$ & $270 a$ \\
\hline $\mathrm{Mg}$ & $\left(\mathrm{mg} \mathrm{kg}^{-1}\right)$ & $975 a$ & $926 a$ & $919 a$ & $853 a$ & $887 a$ & $957 a$ \\
\hline $\mathrm{Fe}$ & $\left(\mathrm{mg} \mathrm{kg}^{-1}\right)$ & $0.13 a$ & $0.10 \mathrm{a}$ & $0.40 \mathrm{a}$ & $0.01 \mathrm{~b}$ & $0.58 \mathrm{a}$ & $0.01 \mathrm{~b}$ \\
\hline TDN & $\left(\mathrm{mg} \mathrm{kg}{ }^{-1}\right)$ & $321 a$ & $251 \mathrm{a}$ & $272 \mathrm{a}$ & $306 a$ & $280 a$ & $220 \mathrm{a}$ \\
\hline TDP & $\left(\mathrm{mg} \mathrm{kg}^{-1}\right)$ & $19 a$ & $17 a$ & $26 a$ & $16 \mathrm{~b}$ & $24 \mathrm{a}$ & $17 a$ \\
\hline Eh & $(\mathrm{mV})$ & $162 \mathrm{a}$ & $-31 b$ & $120 a$ & $-140 b$ & $116 a$ & $-156 b$ \\
\hline
\end{tabular}


high sulfide conditions also may have induced shifts from oxidative to fermentative metabolism in the root tissue because of lowered soil redox potentials (Howes et al. 1981, Mendelssohn et al. 1981). Such a shift would result in decreased energy for nutrient uptake and growth. This may have occurred in the SS sites of North Inlet as indicated by the inverse relationships between shoot $\mathrm{S}$ and shoot $\mathrm{N}(r=-0.39, p<0.01, n=$ 124), $\mathrm{P}(r=-0.50, p<0.001, n=124)$, and $K(r=-0.24$, $p<0.01, n=124)$. The results of other researchers (King et al. 1982, DeLaune et al. 1983) support these findings.

The third interstitial water parameter, along with Eh and sulfide, that differed between the 2 study sites was Fe concentration (Table 4). Pools of Fe were greater at the TS site than at the SS site. King et al. (1982) explained that concentrations of sulfide at Sapelo Island were the result of differential precipitation of iron sulfide at the various sites. Perhaps the potential for precipitation of sulfide was much less in SS than in IS sites because of the smaller pools of dissolved interstitial $\mathrm{Fe}$ in the SS soils.

\section{Ratios of nitrogen to other macronutrients}

The ratios of $\mathrm{N}: \mathrm{K}, \mathrm{N}: \mathrm{Ca}$, and $\mathrm{N}: \mathrm{Mg}$ were similar between TS and SS stems and TS and SS roots (Table 1). However, the ratio of $\mathrm{N}: \mathrm{P}$ in TS roots $(4.4: 1)$ was lower than that in SS roots $(7.0: 1)(p<0.05, n=$ 126). Since $N$ concentrations in TS roots were significantly greater than in SS roots (Table 1), this means there was a greater proportion of $\mathrm{P}$ in TS roots than in $\mathrm{SS}$ roots. This greater proportion of $\mathrm{P}$ to $\mathrm{N}$ in TS roots may have influenced the TS and SS growth forms.

The $\mathrm{N}$ : S ratio was another apparent nutrient disproportionality between TS and SS $44.1: 1$ and 1.5:1, respectively). Although the $\mathrm{N}$ concentrations were significantly greater in TS stems than SS stems (Table 1), we concluded that there was likely a critical proportionality of N:S which, in the case of SS, was probably exceeded by significantly greater $\mathrm{S}$ concentrations in SS stems than in TS stems (Table 1).

\section{CONCLUSIONS}

Our results support the hypothesis that the macronutrient status may account for the height and biomass differences between the tall and short forms of Spartina alterniflora. Ammonia as well as total dissolved nitrogen concentrations were similar in the soils of both TS and SS sites suggesting that $N$ availability was not limiting SS growth. However, $N$ concentrations were greater in shoots and roots of TS than in SS. This is one indication that the $\mathrm{N}$ status of SS was deficient relative to that of the tall form. Soil sulfide also may have played a role in the height and biomass differences between the 2 forms. Both shoot and root $S$ concentrations were greater in SS than in TS. We speculate that the high concentrations of $\mathrm{S}$ in SS may have prevented the uptake or assimilation of N. Lower Fe levels were noted in the SS than TS interstitial waters. Lower redox potentials (Eh) and Fe availability resulted in higher sulfide levels which may have decreased plant production.

Seasonal patterns of macronutrient concentrations in both TS and SS followed similar trends. Shoot tissue N, $P$, and $S$ changed over time while $K, C a$, and $\mathrm{Mg}$ generally did not change throughout the year.

Acknowledgements. We thank Drs John Vernberg, Richard Dame, and Bob Gardner, and the staff of the Belle W. Baruch Institute for Marine Biology and Coastal Research for the collection and processing of Spartina alterniflora tissues and sharing biomass and soil data. We are especially indebted to Mr Paul Kenny and Dr Richard Dame who made sure sufficient quantities of tissues were collected beyond those needed for their own Primary Production Project and who shared their data with us. Thanks also to Mr David Stilwell and Ms Carol Schmidt who aided in the collection and processing of samples in the earliest stages of the project. Dr Bob Gardner, USC Geology Department, was very helpful in supplying data on soil chemistry. Thanks also to Dr Domy Adriano, Patrick Megonigal, Dr Jodi Shann, and Claire Carlson of the Savannah River Ecology Laboratory, for their critical reviews of this manuscript. Special thanks to Brends Watkins for her extra efforts in quickly producing clean documents. This work was part of the North Inlet Long Term Ecological Research (LTER) project supported by NSF grant DEB 8012165. This publication is No. 750 of the Belle W. Baruch Institute for Marine Biology and Coastal Research. Portions of this study also were funded by the University of South Carolina Faculty Exchange Program and University of South Carolina-Aiken. Additional support was provided from contract DE-ACO9-76SROD-819 between the D.O.E. and the University of Georgia's Savannah River Ecology Laboratory.

\section{LITERATURE CITED}

Adams, D. A. (1963). Factors influencing vascular plant zonation in North Carolina salt marshes. Ecology 44: 445-456

Anderson, C. M., Treshow, M. (1980). A review of environmental and genetic factors that affect height in Spartina alterniflora Loisel. (Salt Marsh Cord Grass). Estuaries 3 $168-176$

Broome, S. W., Seneca, E. D., Woodhouse, W. W. Jr (1986) Long-term growth and development of transplants of the salt-marsh grass Spartina alterniflora. Estuaries 9: 63-74

Broome, S. W., Woodhouse, W W., Jr, Seneca, E. D. (1975). The relationship of mineral nutrients to growth of Spartina alterniflora in North Carolina. II. The effects of N, P, and Fe fertilizers. Soil Sci. Soc. Am. Proc. 39: 301-307

Burkholder, P. R. (1956). Studies on the nutritive value of Spartina grass growing in the marsh areas of coastal Georgia. Bull. Torrey Bot. Club 83: 327-334

Butters, B., Chenery, E. M. (1959). A rapid method for the 
determination of total sulfur in soils and plants. Analyst 84 : $239-245$

Carlson, P. R., Forrest, J. (1982). Uptake of dissolved sulfide by Spartina alterniflora: evidence from natural sulfur isotope abundance ratios. Science 216: 633-635

Chalmers, A. G. (1979). The effects of fertilization on nitrogen distribution in a Spartina alterniflora salt marsh. Estuar. coast. mar. Sci. 8: 327-337

Council on Soil Testing and Plant Analysis (1980). Handbook on reference methods for soil testing. University of Georgia Press, Athens, Georgia

Dame, R. F., Kenny, P. D. (1986). Variability of Spartina alterniflora primary production in the euhaline North Inlet estuary. Mar. Ecol. Prog. Ser. 32: 71-80

DeLaune, R. D., Reddy, C. N., Patrick, W H. Jr (1981) Accumulation of plant nutrients and heavy metals through sedimentation processes and accretion in a Louisiana salt marsh. Estuaries 4: 328-334

DeLaune, R. D., Smith, C. J., Patrick, W. H. Jr (1983). Relationship of marsh elevation, Iedox potential, and sulfide to Spartina alterniflora productibity. Soil Sci. Soc. Am. J. 47 930-935

Eley, R. L., Falco, J. W., Kirby, C. J. (1975). The role of physical modeling in marsh-estuarine mineral-cycling research. In: Howell, F. G., Gentry, J. B., Smith, H. M. (eds.) Mineral cycling in southeastern ecosystems. USERDA Symposium Series, CONF-740513. National Technical Information Service, Springfield, Virginia, p. 166-178

Gallagher, J. L. (1975). Effect of an ammonium nitrate pulse on the growth and elemental composition of natural stands of Spartina alterniflora and Juncus roemerianus. Am. J. Bot. 62: 644-648

Gallagher, J. L., Reinold, R. J., Linthurst, R. A., Pfeiffer, W. J. (1980). Seasonal production, mortality, and mineral accumulation-export dynamics in Spartina alterniflora and Juncus roemerianus plant stands in a Georgia salt marsh. Ecology 61: 303-312

Giblin, A. E., Howarth, R. W. (1984). Porewater evidence for a dynamic sedimentary iron cycle in salt marshes. Limnol. Oceanogr. 29: 47-63

Giurgevich, J. R., Dunn, E. L. (1979). Seasonal patterns of $\mathrm{CO}_{2}$ and water vapor exchange of the tall and short height forms of Spartina alterniflora Loisel. in a Georgia salt marsh. Oecologia (Berl.) 43: 139-156

Gosselink, J. G. (1984). The ecology of delta marshes of coastal Louisiana: a community profile. U. S. Fish and Wildlife Service FWS/OBS-84/09

Hopkinson, C. S., Schubauer, J. P. (1984). Static and dynamic aspects of nitrogen cycling in the salt marsh graminoid Spartina alterniflora. Ecology 65: 961-969

Howarth, R. W., Teal, J. M. (1979). Sulfate reduction in a New England salt marsh. Limnol. Oceanogr. 24: 999-1013

Howes, B. L., Howarth, R. W., Teal, J. M., Valiela, I. (1981). Oxidation-reduction potentials in a salt marsh: spatial patterns and interactions with primary production. Limnol. Oceanogr. 26: 350-360

Jones, J. B., Jr, Isaac, R. A. (1972). Determination of sulfur in plant material using a Leco Sulfur Analyzer. J. agric. Fd Chem. 20: 1292-1294

Kammerer, P. E., Rochel, M. G., Hughes, R. A., Lee, G. F (1967). Low level Kjeldahl nitrogen determination on the Technicon Auto analyzer. Environ. Sci. Tech. 1 4-340

King, G. M., Klug, M. J., Wiegert, R. G., Chalmers, A. G (1982). Relation of soil water movement and sulfide concentration to Spartina alterniflora production in a Georgia salt marsh. Science 218: 61-63

Kjerfve, B., Proehl, J., Schwing, F., Seim, H., Maeozas, M.
(1982). Temporal and spatial considerations in measuring estuarine water fluxes. In: Kennedy, $V$ (ed.) Estuarine comparisons. Academic Press, New York, p. 37-51

Linthurst, R. A. (1979). The effect of aeration on the growth of Spartina alterniflora Loisel. Am. J. Bot. 66: 685-691

Linthurst, R. A., Seneca, E. D. (1981). Aeration, nitrogen and salinity as determinants of Spartina alterniflora Loisel. growth response. Estuaries 4: 53-63

Mendelssohn, I. A. (1979a). Nitrogen metabolism in the height forms of Spartina alterniflora in North Carolina. Ecology 60: $574-584$

Mendelssohn, I. A. (1979b). The influence of nitrogen level, form, and application method on the growth response of Spartina alterniflora in North Carolina. Estuaries 2: 106-112

Mendelssohn, I. A., McKee, K. L., Patrick, W H. (1981). Oxygen deficiency in Spartina alterniflora roots; metabolic adaptation to anoxia. Sci. 214:439-441

Miller, W. R., Egler, F. E. (1950). Vegetation of the Wequetequock-Pawcatuck tidal-marshes, Connecticut. Ecol. Monogr 20: 143-172

Morris, J. T. (1980). The nitrogen uptake kinetics of Spartina alterniflora in culture. Ecology 61: 1114-1121

Murphy, J., Riley, J. P. (1962). A modified single solution method for the determination of phosphorus in natural waters. Analytica chim. Acta 27: 30-37

Nestler, J. (1977). Interstitial salinity as a cause of ecophenic variation in Spartina alterniflora. Estuar. coast. mar. Sci. 5: $707-714$

O'Brian, J., Fiore, J. (1962). Ammonia determination by automated analysis. Wastes Eng. 33: 352-357

Patrick, W. H., Jr, DeLaune, R. D. (1976). Nitrogen and phosphorus utilization by Spartina alterniflora in a salt marsh in Barataria Bay, Louisiana. Estuar. coast. mar. Sci. 4: 59-64

Phleger, C. F. (1971). Effect of salinity on growth of a salt marsh grass. Ecology 52: 908-911

SAS Institute (1985). SAS user's guide: statistics. Cary, North Carolina

Shea, M. L., Warren, R. S., Niering, W. A. (1975). Biochemical and transplantation studies of the growth form of Spartina alterniflora on Connecticut salt marshes. Ecology 56: 461-466

Smart, R. M., Barko, J. W. (1980). Nitrogen nutrition and salinity tolerance of Distichlis spicata and Spartina alterniflora. Ecology 61: 630-638

Smith, S. V. (1984). Phosphorus versus nitrogen limitation in the marine environment. Limnol. Oceanogr. 29: 1149-1160

Stevenson, F. J. (1982). Nitrogen in agricultural soils Agronomy monograph No. 22. Am. Soc. Ag., Madison, Wisconsin

Sullivan, M. J., Daiber, F. C. (1974). Response in production of cord grass, Spartina alterniflora, to inorganic nitrogen and phosphorus fertilizer. Chesapeake Sci. 15: 121-123

Valiela, I. (1984). Marine ecological processes. Springer-Verlag, New York, p. 66-67, 234-235, 410-411

Valiela, I., Teal, J. M. (1974). Nutrient limitation in salt marsh vegetation. In: Reinold, R. J., Queen, W. H. (eds.) Ecology of halophytes. Academic Press, New York, p. 547-563

Valiela, I., Teal, J. M., Pearson, N. Y (1976). Production and dynamics of experimentally enriched salt marsh vegetation: belowground biomass. Limnol. Oceanogr. 21: 245-252

Valiela, I., Teal, J. M., Sass, W. J. (1975). Production and dynamics of salt marsh vegetation and the effect of experimental treatment with sewage sludge. J. appl. Ecol. 12: 973-981

Whitney, D. E., Chalmers, A. G., Haines, E. B., Hansen, R. B. Pomeroy, L. R., Sherr, B. (1981). The cycles of nitrogen and phosphorus. In: Pomeroy, L. R., Wiegert, R. G. (eds.) The 
ecology of a salt marsh. Springer-Verlag, New York, p. $163-181$

Wolaver, T G., Zieman, J. (1984). The role of tall and medium Spartina alterniflora zones in the processing of nutrients in tidal water. Estuar. Coast. Shelf Sci. 19: 1-13

This article was submitted to the editor
Woodhouse, W W., Seneca, E. D., Broome, S. W. (1974). Propagation of Spartina alterniflora for substrate stabilization and salt marsh development. Technical Memorandum 46. United States Army Corps of Engineers, Coastal Engineering Research Center, Fort Belvoir, Virginia

Manuscript first received: October 17, 1988 Revised version accepted: April 14, 1989 